\title{
Effects of Pond Fertilization and Feeding of Carp Fry (Cyprinus carpio L.) on Diversity of Zooplankton Groups (Rotifera, Cladocera, and Copepoda)
}

\author{
Irena Bielańska-Grajner ${ }^{1 *}$, Klaudia Cebulska ${ }^{1}$, Klaudia Sojka ${ }^{1}$, \\ Paulina Pałosz ${ }^{1}$, Ludmila Kolek ${ }^{2}$ \\ ${ }^{1}$ Department of Hydrobiology, University of Silesia, Bankowa 9, 40-007 Katowice, Poland \\ ${ }^{2}$ Institute of Ichthyobiology and Aquaculture of the Polish Academy of Sciences in Gołysz, Zaborze, \\ Kalinowa 2, 43-520 Chybie, Poland
}

Received: 12 April 2017

Accepted: 21 June 2017

\begin{abstract}
The aim of our study was to compare the biodiversity of zooplankton in experimental ponds with various combinations of fertilizers and supplementary fish feed. Zooplankton samples were collected twice a month from April to September 2015. Rotifers were the most diverse and the most abundant zooplankton group. The most abundant rotifer species in all the ponds were Anuraeopsis fissa, Keratella cochlearis, Keratella tecta, Polyathra sp., and Trichocerca pusilla, while among cladocerans there was Bosmina longirostris. Optimal conditions for developing the Rotifera were found in the experimental ponds with standard fertilization and standard feeding of fish. The highest biomass was achieved by zooplankton in the ponds with accelerated fertilization and standard feeding of fish.
\end{abstract}

Keywords: zooplankton, fish ponds, pond fertilization, fish feeding

\section{Introduction}

Many authors pay attention to the considerable significance of small water bodies, such as ponds, for the global water economy as well as their contribution to biodiversity [1-4]. As emphasized by Fahd et al. [5], many studies have suggested that ponds may be particularly important for maintaining regional freshwater biodiversity, and this has significant practical implications for waterbody monitoring and protection in catchments.

*e-mail: irena.bielanska-grajner@us.edu.pl
Those authors complained that no European country undertook routine pond or ditch surveillance and even the recently adopted EC Water Framework Directive (2000/60/EC), emphasising a catchment management approach, did not specifically include the terms "pond" and "ditch," making it unlikely that their surveillance would be widely undertaken. Céréghino et al. [6] found that there is a growing awareness in Europe of the importance of ponds, and an increased understanding of the contribution they make to aquatic diversity and catchment functions. Collectively, they support considerably more species and specifically more of the rare species than any other type of freshwater body. The significance of ponds for the 
biodiversity of organisms has been confirmed by studies done in the south of France [7] and in Poland [8]. Ponds and shallow lakes are, collectively, exceptionally rich in terms of biodiversity [5], but they have only recently been recognized as important habitats [9].

Zooplankton can control the species composition and biomass as well as productivity of producers: phytoplankton and bacteria [10-11]. That is why zooplankton plays such an important role both in ponds and in other aquatic ecosystems. The structure of zooplankton can differ between habitats due to physicochemical conditions [6] and the diversity of algal and macrophyte communities [11-12].

Modern pond management is intensive, its aim being to obtain maximum production per pond surface unit [13]. In order to achieve this, it is essential to ensure that fish have optimal environmental conditions, which includes feeding. Carp feed on zooplankton and benthic macroinvertebrates as well as periphyton fauna. The greater the quantity of available feed, the greater the fertility of the given pond. Where there is an increased intensification of fish farming, the availability of natural feed is much too small. Thus the development of aquatic fauna is stimulated by mineral fertilizers, which increase the food base for the fry [1416]. In order to increase natural productivity in carp farms, organic fertilizers such as manure, slurry, green manure, straw, hay, or soya flour are applied as well as mineral fertilizer [17]. The aim of our study was to compare the biodiversity of zooplankton in experimental ponds with various combinations of fertilizers and supplementary fish feed.

\section{Materials and Methods}

\section{Description of Study Area}

The research was conducted at the Institute of Ichthyobiology and Aquaculture of the Polish Academy of Sciences in Gołysz. It is located in the village of Zaborze in southern Silesia (49 $\left.51^{\prime} 58.27^{\prime \prime} \mathrm{N}, 1^{\circ} 48^{\prime} 30.98^{\prime \prime} \mathrm{E}\right)$ (geoportal.gov.pl), within the Oświęcim Basin macroregion, in the Upper Vistula River Valley mesoregion (southern Poland). Numerous scientific issues related to farming and biology of thermophilic fish are investigated at this institute. Moreover, the institute maintains a live gene bank that includes 17 purebred common carp strains of various geographical origins.

For a fish production research project, 16 fish ponds were chosen and separated into four different experimental variants related to methods of fertilization and carp fry feeding: A) standard fertilization and standard feeding, B) accelerated fertilization and standard feeding, C) standard fertilization and accelerated feeding, and D) accelerated fertilization and accelerated feeding.

Zooplankton analyses were carried out in eight of these ponds (two of each experimental variant). Each pond had a surface area of about 0.072 ha, with a maximum depth of
$1.5 \mathrm{~m}$. The studied ponds had been filled with water from the Vistula River and on 1 April 2014 each of them was stocked with 250 individuals of carp fry, with an average unit weight of about $70 \mathrm{~g}$. The ponds were fertilized with a nitrogen fertilizer (urea, $180 \mathrm{~kg} \mathrm{~N} / \mathrm{ha}$ ) in the standard method (18 even portions from 14 April to 12 August, $1.56 \mathrm{~kg} /$ pond once a week) or in the accelerated method (21 uneven portions from 7 March to 12 August, the first three portions of $2.81 \mathrm{~kg} /$ pond each, next 18 weekly portions of $1.10 \mathrm{~kg} /$ pond each). The ponds were also fertilized with a phosphorous fertilizer (superphosphate, $30 \mathrm{~kg} \mathrm{P} / \mathrm{ha}$ ) in the standard method (18 even portions from 8-14 April to 11 August, $0.68 \mathrm{~kg} /$ pond once a week) or in the accelerated method (19 uneven portions from 8 April to 12 August, the first portion of $2.44 \mathrm{~kg} /$ pond, the next 18 weekly portions of $0.54 \mathrm{~kg} /$ pond each).

In addition, two methods of fish feeding were applied: the standard cycle was started on 28 April, and the accelerated cycle on 7 April. Fish in each pond were fed weekly with ground grain. The studied ponds were overgrown with floating-leaved macrophytes: Persicaria amphibia (L), Potamogeton lucens L., Sagittaria sagittifolia L., and Lemna minor L. The water of the studied ponds was characterized by a low average oxygen content. In the summer period, during the time of strong growth of duckweed (Lemna minor), a lack of dissolved oxygen was observed (Table 1). Electrical conductivity was relatively high, the highest in the ponds with variant A of fertilization and feeding, and the lowest was in the ponds with variant $\mathrm{C}$ of fertilization and feeding (Table 1).

\section{Methods of Assessing Zooplankton Biological Diversity}

Analyses of the physical and chemical parameters of water, i.e., conductivity, total dissolved solids, temperature, and $\mathrm{pH}$, were measured in the field, using a portable $\mathrm{HI}$ 9811-5 $\mathrm{pH} / \mathrm{EC} / \mathrm{TDS} /{ }^{\circ} \mathrm{C}$ meter HI 9811-5 (Hanna Instruments), dissolved oxygen with OxiCal-SL oxygen meter, and turbidity with a EUTECH TN-100 meter (Table 1).

Zooplankton samples were collected twice a month from April to September 2015. For quantitative analyses, the samples $\left(10 \mathrm{dm}^{3}\right)$ were concentrated on a plankton net (mesh size $30 \mu \mathrm{m}$ ). The material was fixed with Lugol fluid and preserved in a formalin solution (4\%). Rotifer species were classified according to Segers [18], while cladocerans and copepods, according to Rybak and Błędzki [19].

The diversity of zooplankton was described using the Shannon diversity index, Pielou evenness index, and Margalef species richness index. All analyses were performed in MVSP 3.1 software.

\section{Statistical Analysis}

The statistical significance of differences between the experimental variants in biomass, abundance, and 
Table 1. Results of physicochemical analysis of water.

\begin{tabular}{|c|c|c|c|c|c|}
\hline Parameter & Type of experiment & Min. & Max. & Average value & Standard deviation \\
\hline \multirow{4}{*}{ Temperature $\left({ }^{\circ} \mathrm{C}\right)$} & A & 8.38 & 24.70 & 18.05 & 4.22 \\
\hline & B & 9.33 & 24.80 & 17.78 & 3.85 \\
\hline & $\mathrm{C}$ & 9.30 & 24.30 & 17.97 & 4.04 \\
\hline & $\mathrm{D}$ & 8.90 & 24.70 & 18.10 & 4.13 \\
\hline \multirow{4}{*}{$(\mathrm{pH})$} & A & 5.30 & 8.38 & 7.33 & 0.72 \\
\hline & B & 6.91 & 9.39 & 7.64 & 0.72 \\
\hline & $\mathrm{C}$ & 5.20 & 9.62 & 7.42 & 0.90 \\
\hline & $\mathrm{D}$ & 5.10 & 9.20 & 7.00 & 0.88 \\
\hline \multirow{4}{*}{$\begin{array}{l}\text { Disolved oxygen } \\
\qquad\left(\mathrm{mg} / \mathrm{dm}^{3}\right)\end{array}$} & A & 0.68 & 11.83 & 6.19 & 3.54 \\
\hline & B & ns & 16.36 & 5.83 & 5.05 \\
\hline & $\mathrm{C}$ & 1.02 & 14.55 & 6.50 & 3.58 \\
\hline & $\mathrm{D}$ & 0.00 & 15.81 & 6.42 & 4.53 \\
\hline \multirow{4}{*}{$\begin{array}{l}\text { Electrical conducti- } \\
\quad \text { vity }(\mu \mathrm{S} \mathrm{cm})\end{array}$} & A & 150 & 710 & 307.22 & 172.79 \\
\hline & B & 170 & 490 & 230.56 & 71.16 \\
\hline & $\mathrm{C}$ & 160 & 340 & 223.89 & 53.37 \\
\hline & $\mathrm{D}$ & 160 & 550 & 245 & 89.59 \\
\hline \multirow{4}{*}{$\begin{array}{l}\text { Organic matter } \\
\qquad(\mathrm{mg} / \mathrm{l})\end{array}$} & A & 70 & 330 & 152.78 & 79.40 \\
\hline & B & 80 & 230 & 110.00 & 33.25 \\
\hline & $\mathrm{C}$ & 70 & 170 & 106.67 & 27.44 \\
\hline & $\mathrm{D}$ & 70 & 260 & 112.22 & 44.00 \\
\hline \multirow{4}{*}{$\mathrm{COD}\left(\mathrm{mg} \mathrm{O}_{2} / \mathrm{dm}^{3}\right)$} & A & 21.00 & 99.60 & 41.03 & 18.55 \\
\hline & $\mathrm{B}$ & 13.64 & 56.51 & 31.94 & 12.54 \\
\hline & $\mathrm{C}$ & 10.70 & 67.49 & 34.12 & 14.23 \\
\hline & $\mathrm{D}$ & 19.40 & 52.00 & 34.02 & 10.85 \\
\hline \multirow{4}{*}{ 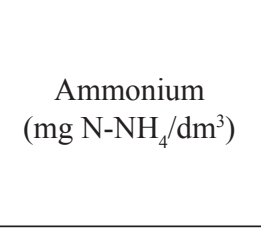 } & A & ns & 1.03 & 0.11 & 0.25 \\
\hline & B & $\mathrm{ns}$ & 1.02 & 0.18 & 0.34 \\
\hline & $\mathrm{C}$ & ns & 1.36 & 0.22 & 0.44 \\
\hline & $\mathrm{D}$ & ns & 1.35 & 0.23 & 0.37 \\
\hline \multirow{4}{*}{ Turbidity (NTU) } & A & 1.33 & 22.60 & 10.35 & 6.17 \\
\hline & B & 2.55 & 19.19 & 7.93 & 3.93 \\
\hline & $\mathrm{C}$ & 4.02 & 43.30 & 12.24 & 10.24 \\
\hline & $\mathrm{D}$ & 2.62 & 13.75 & 8.24 & 3.83 \\
\hline
\end{tabular}

species diversity of rotifers, cladocerans, copepods, and all zooplankton was tested by a nonparametric test: Kruskal-Wallis one-way analysis of variance (ANOVA). Cluster analysis by agglomeration was also made (Ward method, based on Euclidean distance) to compare the faunistic similarities between the experimental variants. All statistical analyses were performed by the statistical program STATISTICA for Windows v. 10.0.

\section{Results}

Species Richness and Species Diversity of Zooplankton

Altogether, 146 species of zooplankton were found in the studied ponds. These included 106 Rotifera species, 28 Cladocera species, and 12 Copepoda species. All the 
studied ponds were characterized by a large abundance of rotifer species. The highest average number of zooplankton taxa (71) was found in the ponds with standard fertilizing and feeding (A) and those with accelerated fertilizing and standard feeding (B), whereas the smallest number of taxa (68) was found in the ponds with accelerated fertilizing and accelerated feeding (D).

The most abundant rotifer species in all the ponds were Anuraeopsis fissa (Gosse), Keratella cochlearis (Gosse), K. tecta (Gosse), Polyathra sp., and Trichocerca pusilla (Laut.). Among the water fleas, Bosmina longirostris (O. F. Müll.) was the most abundant, present in all the ponds. Also in all the ponds (except variant A), but not many Daphnia cucullata G. O. Sars and D. longispina (O. F. Müll.) were found. Among the Copepoda, the most abundant were the young forms of nauplii of the Calanoida and Cyclopida.

Some of the rotifers recorded in the ponds are rare in Polish fauna: Filinia opoliensis (Zach.), Brachionus falcatus Zach., and Proalides tentaculatus De Beauch. In the studied ponds the highest Shannon diversity index $\left(H^{\prime}\right)$ was found for the Rotifera while the lowest was for the Cladocera. The highest $H$ ' for the Rotifers was found in ponds $C_{1}(2.55)$ and $B_{2}(2.41)$, whereas the Margalef
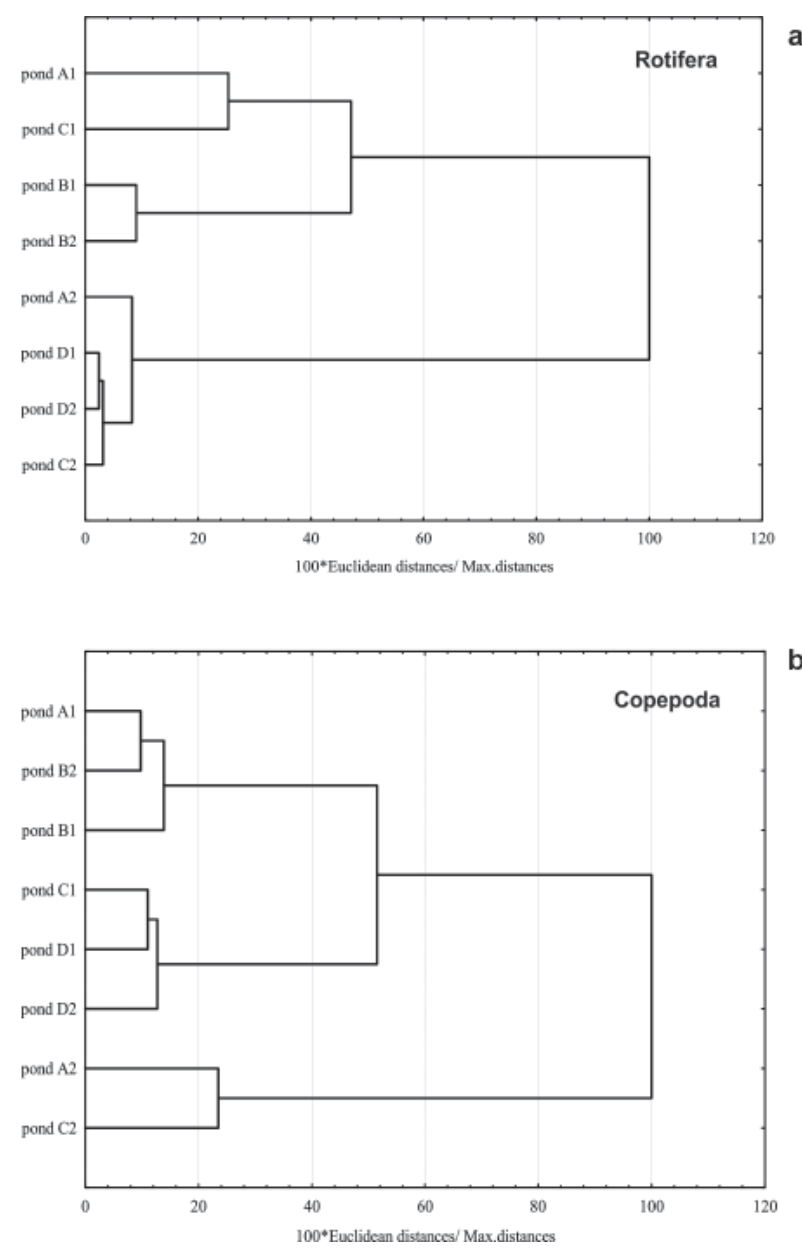

Fig. 1 Dendrogram of faunal similarities for Rotifers and Cladocera in experimental ponds a) Rotifers, b) Cladocera. index was the highest in ponds $\mathrm{C}_{2}$ and $\mathrm{A}_{1}$. The Copepoda achieved the highest $H^{\prime}$ in ponds $\mathrm{B}_{2}$ and $\mathrm{A}_{1}$, and the water fleas in ponds $\mathrm{B}_{1}$ and $\mathrm{C}_{2}$. The Margalef index for crustaceans was low and there were no clear differences between all the ponds. No statistically significant differences in the indices of biological diversity for the whole zooplankton as well as for individual groups of zooplankton between the experimental variants were demonstrated.

No similarity of groupings of the whole zooplankton was found in the ponds studied, but the groupings of Rotifera were similar in ponds $\mathrm{B}_{1}$ and $\mathrm{B}_{2}$ (with accelerated fertilization and standard feeding) and in ponds $\mathrm{D}_{1}$ and $\mathrm{D}_{2}$ (with accelerated fertilization and accelerated feeding). Based on the similarity of rotifer groupings, it is possible to separate two groups of ponds. The first group comprises ponds $\mathrm{A}_{1}$ and $\mathrm{C}_{1}$ as well as $\mathrm{B}_{1}$ and $\mathrm{B}_{2}$, and the second group comprises ponds $A_{2}, D_{1}$, and $D_{2}$ as well as $C_{2}$ (Fig. 1a). Based on the groupings of Cladocera, however, ponds $\mathrm{C}_{1}$ and $\mathrm{C}_{2}$ (with standard fertilizing and accelerated feeding) were similar. In the remaining ponds, the method of fertilization and feeding had no influence on the similarity of Cladocera groupings (Fig. 1b). There was no similarity of Copepoda groupings between the ponds.

\section{Quantitative Structure of Zooplankton}

The density and biomass of zooplankton in the studied experimental ponds of the Institute of Ichthyobiology and Aquaculture were similar to those reported by Szumiec et al. [20]. The density of zooplankton in the ponds ranged from $2,810 \mathrm{ind} . / \mathrm{dm}^{3}$ in pond $A_{1}$ to $450 \mathrm{ind} . / \mathrm{dm}^{3}$ in pond $\mathrm{C}_{2}$ (Fig. 2a), with the Rotifera being dominant. The greatest
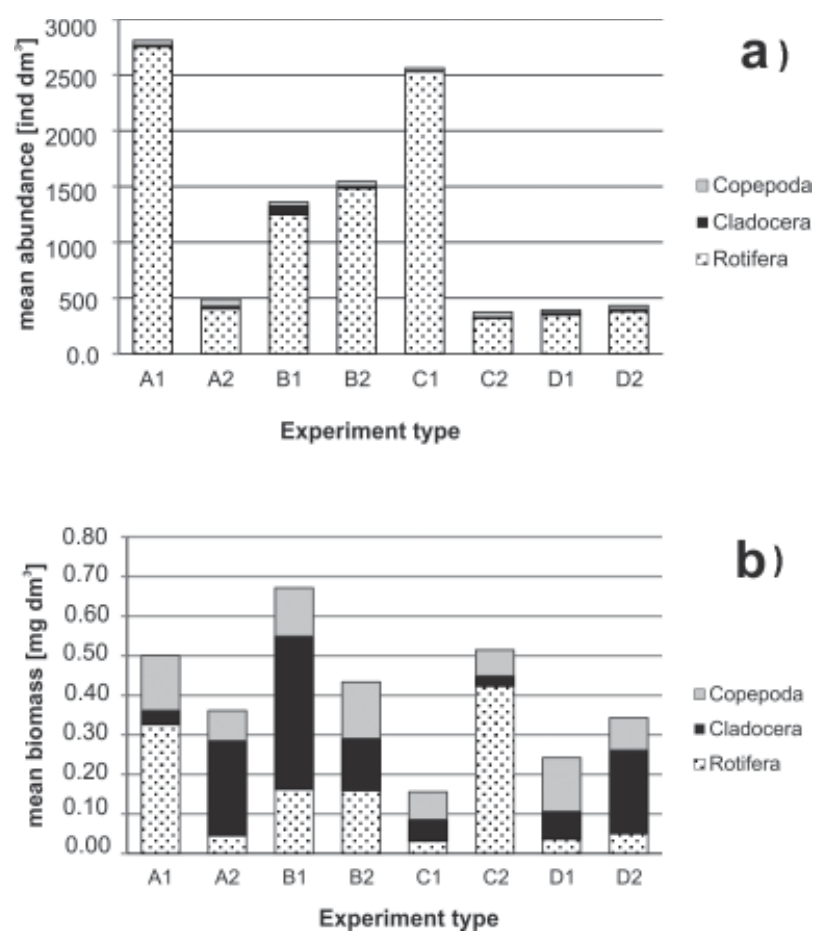

Fig. 2 Mean densities and biomass of zooplankton groups in all types of experimental ponds a) density, b) biomass. 
density of Rotifera was in ponds $\mathrm{A}_{1}\left(2,750 \mathrm{ind} . / \mathrm{dm}^{3}\right)$ and $\mathrm{C}_{1}\left(2,500 \mathrm{ind} . / \mathrm{dm}^{3}\right)$. In the remaining ponds, it varied between 1,500 ind. $/ \mathrm{dm}^{3}$ and 400 ind. $/ \mathrm{dm}^{3}$. The average density of zooplankton in all the ponds was 1,183 ind./ $\mathrm{dm}^{3}$ (Fig. 2a).

The greatest density in all variants of the experiment was recorded for the Rotifera and the lowest for the Copepoda. No statistically significant differences in density of the whole zooplankton were found between variants of the experiment. Statistically significant differences between the experimental variants were found in the density of rotifers (ponds $\mathrm{A}$ and $\mathrm{D})$ (ANOVA, $p<0.05$ ) and in the density of water fleas (ponds B and D) (ANOVA, $p<0.05$ ) (Figs 3a-c). Optimal conditions for the Rotifera were found in ponds with standard fertilizing and feeding, while for the Cladocera in ponds with accelerated fertilizing and standard feeding. No statistically significant differences in the density of Copepoda were found between the experimental variants.

The highest average biomass was found in ponds of variant B (with accelerated fertilizing and standard feeding). In most ponds a higher biomass was attained
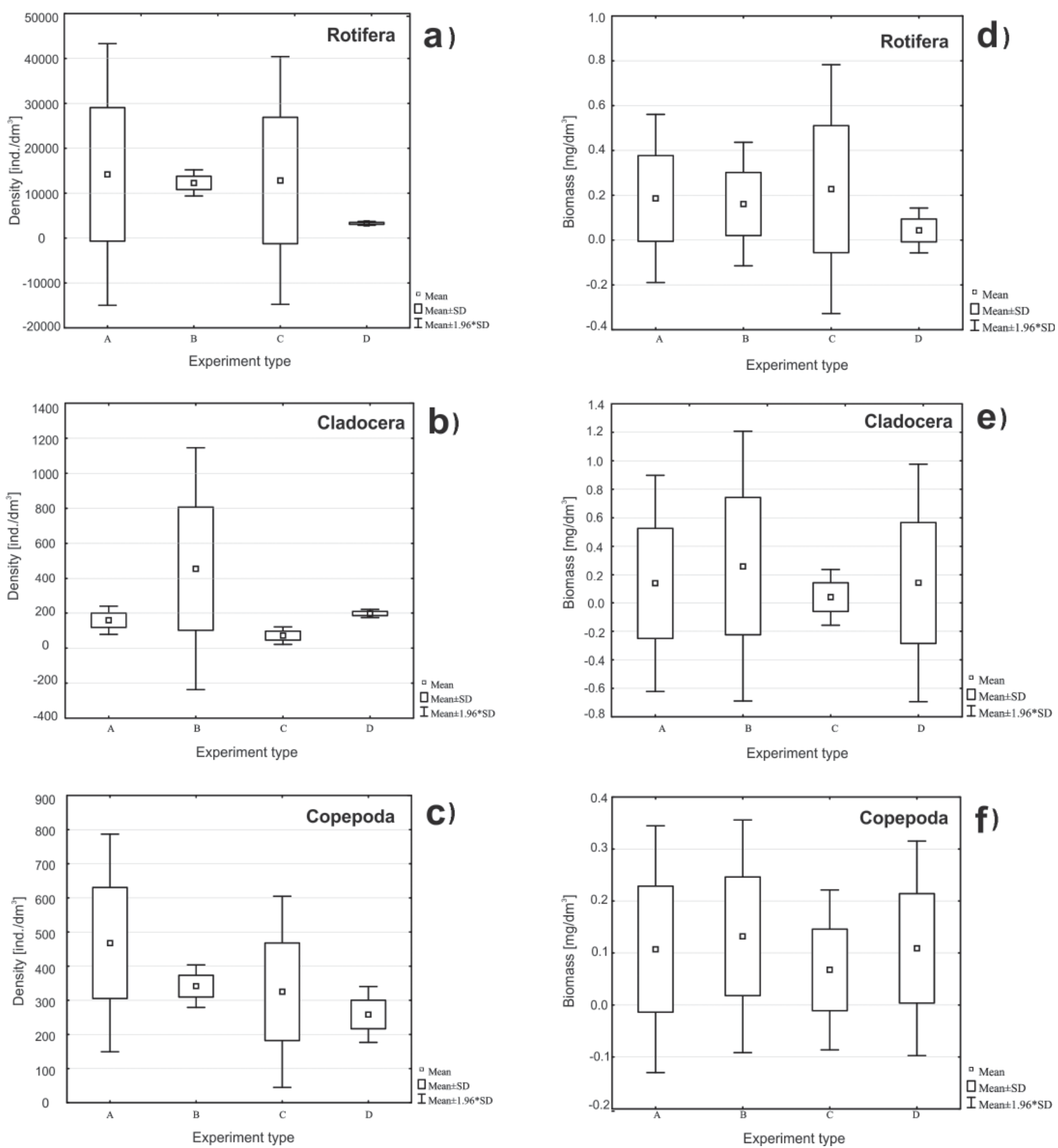

Fig. 3 Mean densities and biomass of several zooplankton groups in all types of experimental ponds. 
by Cladocera compared to Copepoda (Fig. 2b). No statistically significant differences in the biomass of the whole zooplankton between the variants of the experiment were found. Statistical analyses show significant differences in the biomass of rotifers between the variants of the experiment (ponds B and D) (ANOVA, $p<0.05$ ). No statistically significant differences in Crustacea biomass were found between experimental variants (Figs 3d-f).

\section{Discussion}

Our study of zooplankton in the experimental ponds in Gołysz confirms the opinion of many authors [1-3] that ponds support high biodiversity. The zooplankton of the studied experimental ponds were characterized by a great species richness: 146 taxa, including 106 species of Rotifera, 28 species of Cladocera, and 12 species of Copepoda. A lower number of taxa, 103, was found in ponds in Slovakia [21] as well as in farm ponds of Andalusia in southern Spain [22]. Somewhat fewer, 97 taxa of zooplankton, were found in ponds in an agritourist farm [23], and considerably fewer - only 54 taxa of zooplankton - in fish ponds periodically fed with treated wastewater [24]. Such a low number of zooplankton taxa was probably caused by the occasional inflow of wastewater to the studied ponds.

Minor species such as the rotifers Anuraeopsis fissa, Keratella cochlearis, K. tecta, and Polyartha sp., as well as the cladocerans Bosmina longirostris and Chydorus sphaericus (O. F. Müll.), occurred most frequently in the studied experimental ponds. These are considered by many authors to be good indicators of a high water trophic level [25].

High values of diversity indices of Rotifera were found in the studied ponds, similar to those observed for the whole zooplankton in other fish ponds [23-24]. However, the Crustacea (Cladocera and Copepoda) achieved higher species diversity than the Rotifera in the experimental ponds.

The density of rotifers in the experimental ponds reached 2,750 ind./ $/ \mathrm{dm}^{3}$ in pond $A_{1}$ and 2,500 ind./dm in pond $\mathrm{C}_{1}$. In the remaining ponds it ranged from $1,500 \mathrm{ind} . / \mathrm{dm}^{3}$ to $400 \mathrm{ind} . / \mathrm{dm}^{3}$.

Szumiec et al. [20] studied the effects of falling temperatures on the development of zooplankton and phytoplankton in carp breeding ponds. In the years when water temperature was high, the Rotifera achieved high densities. However, the Crustacea were more abundant in colder years, when the species Bosmina longirostris dominated the zooplankton. The densities of zooplankton observed in our study were similar to those observed earlier in warm periods by Szumiec et al. [20]. During the study period the temperature was quite high and the water levels in the studied ponds decreased by a few centimetres due to evaporation, when probably the high temperature caused the dominance of the Rotifera.

In Bangladesh, zooplankton in ponds with various fish-feeding methods were also studied and the highest density occurred in fertilized ponds, while the lowest was in unfertilized ponds [16]. In the cited study the Cladocera had the lowest densities, whereas in our study the Copepoda had the lowest densities.

Brucet et al. [26] also studied the influence of various factors on zooplankton and found that zooplankton were most strongly affected by predators (fish or invertebrates). However, the experiment carried out by Ćirić et al. [27] showed that protein-enriched feed applied to carp ponds had a positive effect on the development of large Cladocera and Copepoda in the zooplankton of the ponds. Vakkilainen et al. [28] also studied the influence of predatory fish and additional feeding on zooplankton. They found that both the feed and the fish affect the zooplankton grouping. The fish in particular influence the density and biomass of zooplankton. If the fish consume the large Cladocera, then the small zooplankton organisms can develop. In our study, zooplankton were dominated by small forms of rotifers, water fleas, and copepods, so the larger forms were probably devoured by fish or by predatory invertebrates.

\section{Conclusions}

The experimental ponds of the Polish Academy of Sciences in Gołysz were characterized by a great richness of Rotifera species and fairly high values of diversity indices of this group of zooplankton. Optimal conditions for the development of the Rotifera were found in the experimental variant with standard fertilizing and standard feeding of fish. The highest biomass of zooplankton was recorded in the ponds with accelerated fertilizing and standard feeding of fish.

\section{Acknowledgements}

We thank Sylwia Ufnalska MSc, MA, for correcting and revising our manuscript.

\section{References}

1. OERTLI B., CÉRÉGHINO R., HULL A., MIRACLE R. Pond conservation: from science to practice. Hydrobiologia 634, 1, 2009.

2. DOWNING J. A. Emerging global role of small lakes and ponds: little things mean a lot. Limnetica 29 (1), 9, 2010.

3. MIRACLE R., OERTLI B., CÉRÉGHINO R., HULL A., ANDREW P. Preface: conservation of european pondscurrent knowledge and future needs. Limnetica 29 (1), 1, 2010.

4. BOIX D., BIGGS J., CÉRÉGHINO R., HULL A.P., KALETTKA T., OERTLI B. Pond research and management in Europe: "Small is Beautiful". Hydrobiologia 689, 1, 2012.

5. FAHD K., ARECHEDERRA A., FLORENCIO M., LEON D., SERRANO L. Copepods and branchiopods of temporary ponds in the Doñana Natural Area (SW Spain): a four decade record (1964-2007). Hydrobiologia 634, 219, 2009. 
6. CÉRÉGHINO R., BIGGS J., OERTL, B. DECLERCK S. The ecology of European ponds: Defining the characteristics of a neglected freshwater habitat. Hydrobiologia 597, 1, 2008.

7. CÉRÉGHINO R., RUGGIERO A., MARTY P., ANGE'LIBERT S. Biodiversity and distribution patterns of freshwater invertebrates in farm ponds of a southwestern French agricultural landscape. Hydrobiologia 597 (1), 43, 2007.

8. KUCZYŃSKA-KIPPEN N. Functioning of plankton communities in habitat differentiated small water bodies of the Wielkopolska area. Bonami, Poznań, pp. 505, 2009 [In Polish].

9. BIGGS J., WILLIAMS P., WHITFIELD M., NICOLET P., WEATHERBY A. 15 years of pond assessment in Britain: results and lessons learned from the work of Pond Conservation. Aquat. Conserv. Mar. Freshw. Ecosyst. 15, 693, 2005.

10. HAGLUND A. L., HILLEBRAND H. The effect of grazing and nutrient supply on periphyton associated bacteria. Microbiol. Ecol. 52 (1), 31, 2006.

11. KUCZYŃSKA-KIPPEN N., JONIAK T. The Impact of Water Chemistry on Zooplankton Occurrence in Two Types (Field versus Forest) of Small Water Bodies. Internat. Rev. Hydrobiol. 95 (2), 130, 2010.

12. TESSIERT C., CATTANEOL A., PINEL-ALLOUL B., HUDON C., BORCARD D. Invertebrate communities and epiphytic biomass associated with metaphyton and emergent and submerged macrophytes in a large river. Aquat. Sci. 70, 10, 2008.

13. SOHAIL M., QURESHI N, A., KHAN N., KHAN M. N., IQBAL K. J., ABBAS F. Effect of Supplementary Feed, Fertilizer and Physico-Chemical Parameters on Pond Productivity Stocked With Indian Major Carps in Monoculture System. Pakistan J. Zool. 46 (6), 1633, 2014.

14. PARK K. S., SHIN H.W. Studies on phyto-and-zooplankton composition and its relation to fish productivity in a west coast fish pond ecosystem. Journal of Environmental Biology. 28 (2), 415, 2007.

15. RAHMAN M.M., NAGELKERKE L.A.J., VERDEGEM M.C.J., WAHAB M.A., VERRETH J.A.J. Relationships among water quality, food resources, fish diet and fish growth in polyculture ponds: A multivariate approach. Aquaculture. 275, 108, 2008.

16. HOSSAIN S., RAHMAN M.M., AKTER M., BHOWMIK S. Species Composition and Abundance of Zooplankton Population in Freshwater Pond of Noakhali District, Bangladesh. World Journal of Fish and Marine Sciences 7 (5), 387, 2015.

17. RAHMAN M.M. Role of common carp (Cyprinus carpio) in aquaculture production systems. Frontiers in Life Science 8 (4), 399, 2015.
18. SEGER S H. Annotated checklist of the rotifers (Phylum Rotifera), with the notes on nomenclature, taxonomy and distribution. Zootaxa. 1564, 1, 2007.

19. RYBAK J. I., BŁĘDZKI L. A. Freshwater planktonic crustaceans. Publisher Warsaw University, Warsaw, pp. 366, 2010 [In Polish].

20. SZUMIEC M., JAKUBAS M., KOLASA-JAMIÑSKA B., URBANIEC-BRÓZDA W. The effect of temperature decrease on carp Cyprinus carpio L. culture in a temperature climate. Part II. Zoo and Phytoplankton dynamics and the chemical composition of pond water. Arch. Pol. Fish. 9 (2), 209, 2001.

21. ILlOVÁ M., PASTUCHOVÁ Z. The zooplankton communities of small water reservoirs with different trophic conditions in two catchments in western Slovakia. Limnologica 42, 271, 2012.

22. LEÓN D., PEÑALVER P., CASAS J., JUAN M., FUENTES F., GALLEGO I., TOJA J. Zooplankton richness in farm ponds of Andalusia (southern Spain). A comparison with natural wetlands. Limnetica 29 (1), 153, 2010.

23. GOŹDZIEJEWSKA A., KARPOWICZ M. Dynamics of zooplankton structure in three small water bodies on the area of an agritourism farm. Teka Commision of Protection and Formation of Natural Environment, PAN. 10, 102, 2013.

24. GOŹDZIEJEWSKA A., TUCHOLSKI S. Zooplankton of fish culture ponds periodically fed with treated westwater. Polish J. of Environ. Stud. 20 (1), 67, 2011.

25. BIELAŃSKA-GRAJNER I., EJSMONT-KARABIN J., RADWAN S. Rotifers Rotifera monogononta. Freshwater fauna of Poland. University of Łódź and Jagiellonian University Press, Łódź - Kraków, 63, 2015.

26. BRUCET S., BOIX D., QUINTANA D., JENSEN E., NATHANSEN L. W., TROCHINE C., MEERHOFF M., GASCO'N S., JEPPESENA E. Factors influencing zooplankton size structure at contrasting temperatures in coastal shallow lakes: implications for effects of climate change. Limnol. Oceanog. 55 (4), 1697, 2010.

27. ĆIRIĆ M., SUBAKOV-SIMIĆ G., DULIĆ Z., BJELANOVIĆ K., ČIČOVAČKI S. MARKOVIĆ Z. Effect of supplemental feed type on water quality, plankton and benthos availability and carp (Cyprinus carpio L.) growth in semi-intensive monoculture ponds. Aquaculture Research 46 (4), 777, 2015.

28. VAKKILAINEN K., KAIRESALO T., HIETALA J., BALAYLA D.M., BÉCARES E., VAN DE BUND W. J., VAN DONK E., FERNÁNDEZ-ALÁEZ M., GYLLSTRÖM M., HANSSON L A., MIRACLE M.R., MOSS,B., ROMO S., RUEDA J., STEPHEN D. Response of zooplankton to nutrient enrichment and fish in shallow lakes: a panEuropean mesocosm experiment. Freshwater Biology 49, 1619, 2004. 